\title{
Review
}

\section{Plant biostimulants: physiological responses induced by protein hydrolyzed-based products and humic substances in plant metabolism}

\author{
Serenella Nardi ${ }^{*}$, Diego Pizzeghello, Michela Schiavon, Andrea Ertani
}

University of Padova - Dept. of Agronomy, Food, Natural Resources, Animal and Environment, Viale dell'Università, 16

- 35020 - Legnaro, PD - Italy

${ }^{*}$ Corresponding author <serenella.nardi@unipd.it>

Edited by: Milton Ferreira de Moraes

Received January 07, 2015

Accepted March 24, 2015

\begin{abstract}
In recent years, the use of biostimulants in sustainable agriculture has been growing. Biostimulants can be obtained from different organic materials and include humic substances (HS), complex organic materials, beneficial chemical elements, peptides and amino acids, inorganic salts, seaweed extracts, chitin and chitosan derivatives, antitranspirants, amino acids and other $\mathrm{N}$-containing substances. The application of biostimulants to plants leads to higher content of nutrients in their tissue and positive metabolic changes. For these reasons, the development of new biostimulants has become a focus of scientific interest. Among their different functions, biostimulants influence plant growth and nitrogen metabolism, especially because of their content in hormones and other signalling molecules. A significant increase in root hair length and density is often observed in plants treated with biostimulants, suggesting that these substances induce a "nutrient acquisition response" that favors nutrient uptake in plants via an increase in the absorptive surface area. Furthermore, biostimulants positively influence the activity and gene expression of enzymes functioning in the primary and secondary plant metabolism. This article reviews the current literature on two main classes of biostimulants: humic substances and protein-based biostimulants. The characteristic of these biostimulants and their effects on plants
\end{abstract} are thoroughly described.

Keywords: hormones, nitrogen metabolism, carbon metabolism, phenylpropanoid pathway, stress

\section{Introduction}

Pesticides, phosphorus and nitrate represent the main agricultural pollutants that pose concern for the environment. Agricultural practices, such as the application of nitrogen rich-fertilizers to crops, may increase the nitrate concentration in groundwater to the point that it can exceed the safe threshold limits proposed by the EPA (Goulding et al., 2000). In response to this, crop production over the last few decades has addressed cost-effective, sustainable and environmentally friendly systems to provide high yields and quality of plant derived-food (Vernieri et al., 2006). Despite the main approaches including genetic selection and creation of varieties displaying elevated capacity of nutrient uptake and/or resistance to biotic and abiotic stresses (Kauffman III et al., 2007), the use of biostimulants to promote plant growth has recently gained increasing attention worldwide (Nardi et al., 2002a; Ertani et al., 2009; Ertani et al., 2013). Biostimulants are defined as materials that contain one or more substances and/or microorganisms able to stimulate nutrient uptake and use efficiency by plants, increase plant tolerance to abiotic/biotic stress and improve crop quality when applied in small amounts (De Vasconcelos et al., 2009; Calvo et al., 2014). Furthermore, biostimulants can enhance the activity of rhizosphere microbes and soil enzymes, the production of hormones and/or growth regulators in soil and plants, and the photosynthetic process (Nardi et al., 2009; Gi- annattasio et al., 2013). The mode of action of biostimulants is often unknown and hard to identify, because they derive mainly from complex sources containing multiple bioactive components that, together, may contribute to specific effects in plants (Ertani et al., 2011a, b). For instance, a number of biostimulants contain hormones, such as auxins (Muscolo et al., 1998; Nardi et al., 2000; Pizzeghello et al., 2001; Jindo et al., 2012; Ertani et al., 2012,), gibberellins (Hussain and Boney, 1969), cytokines (Bentler-Mowat et al., 1968; Jennings, 1969; Augier and Harada, 1972; Pizzeghello et al., 2013), and triacontanol (Ries and Violet, 1977; Kumaravelu et al., 2000; Chen et al., 2002; Çavuşoğlu et al., 2008; Ertani et al., 2012), which are recognized as the main active components responsible for the beneficial effects on plant growth. In this review, the characteristics and mode of action of two classes of plant biostimulants, HS and protein hydrolysates, are thoroughly described.

\section{Humic substances}

Humic substances consist of organic material resulting from concerted reactions of various biotic and abiotic processes. This complex assemblage of molecules deriving from plant and animal debris, represents one of the most abundant organic materials on earth. Humic substances are present in both aquatic environments and the atmosphere (Graber and Rudich, 2006; Salma et al., 2010), and represent the major components of the mixture of materials that comprise soil organic matter. 
Soil HS are known to perform several ecological functions, in both natural and anthropogenic ecosystems. They are responsible for soil fertility by influencing structure and porosity through an effect on particle aggregation (Bronick and Lal, 2005). In addition, HS supply nutrients, through both chelating minerals and their own degradation (Stevenson, 1994), and shape soil biota communities, representing the main source of available organic carbon (Kalbitz et al., 2000).

\section{Biological activity of humic substances}

Several authors have found evidence of HS improving plant growth and physiology (Bottomley, 1914a, 1914b, 1917; O'Donnell, 1973; Cacco and Dell'Agnola, 1984; Dell'Agnola and Nardi, 1987; Nardi et al., 1988; Schiavon et al., 2008; Pizzeghello et al., 2013). These positive effects on plants could be ascribed, in the main, to hormone-like activity, as a number of hormones enclosed in the humus structure have been identified (Muscolo et al., 1998; Nardi et al., 2000b; Pizzeghello et al., 2001). In particular, a combination of genetic and molecular biology techniques (Dobbs et al., 2010; Trevisan et al., 2009, 2011) and gas-chromatography mass spectrometry (Jindo et al., 2012) has confirmed the presence of physiologically active indoleacetic acid (IAA) concentrations in HS.

The capacity of HS auxin-like activity to induce root development in plants was first hypothesized by Concheri et al., (1996). This mechanism was further confirmed by Trevisan et al., (2009) using a mutant genotype (aux1) of Arabidopsis thaliana and specific inhibitors of auxin transport or action. The findings obtained showed that HS induced lateral root formation via auxin-like activity, as confirmed by activation of the auxin synthetic reporter DR5::GUS and enhanced transcription of the early auxin responsive gene IAA19.

How IAA is bound to, or in association with, HS is still not well understood (Schulten and Schnitzer, 1998). The carboxylic groups of HS seem to be key receptors for the IAA and regulate its availability (Canellas et al., 2010, 2002; Jindo et al., 2012; Muscolo et al., 2007a, b). IAA is produced by soil bacteria, fungi, and plant root exudates (Rademacher, 1992; Lebuhn and Hartmann, 1993) and might be in association with HS through hydrophobic interactions (van der Waals, $\pi-\pi$, ion-dipole) and hydrogen bonds. According to previous investigations (Piccolo, 2001, 2002), HS are supramolecular aggregates and their stability and reactivity depend on the solution's ionic strength and $\mathrm{pH}$ of the surrounding environment. Low molecular weight organic acids, as well as root exudates, break the macro aggregate structure and generate subunits of biological active molecules (Nardi et al., 1988; Nardi et al., 2002b, 2005; Canellas and Olivares, 2014).

Although the recognized importance of IAA to HS to promote plant growth, there is clear evidence that the simple presence of auxin in the bulk HS is not sufficient to justify all plant physiological responses to these aggregates. Indeed, plants treated with HS often display different behavior in terms of growth and metabolism in comparison to plants treated with the equivalent concentration of IAA (Muscolo et al., 2007a, b). Furthermore, a transcriptomic study by Trevisan et al., (2011) showed that HS exert their effects on plant physiology by means of complex transcriptional networks and indicated that HS exert their function in plants through a multifaceted mechanism of action, partially connected to their recognized auxin activity, but involving also IAA-independent signaling pathways.

The presence of other signaling molecules in the HS structure, or the involvement of different metabolic messengers mediating HS effects was endorsed by other authors (Aguirre et al., 2009; Kovács et al., 2013). Zandonadi et al., (2010), in particular, showed that root development stimulation and the $\mathrm{H}^{+}$-ATPase activation elicited by $\mathrm{HS}$ depend on mechanisms that use $\mathrm{NO}$ as a messenger that is induced in the early stages of lateral root development.

Humic substances can also display gibberellin (Nardi et al., 2000; Pizzeghello et al., 2002) and cytokinin-like activities (Nardi et al., 1988; Piccolo et al., 1992; Muscolo et al., 1996). Pizzeghello et al., (2013), in particular, demonstrated that HS contain a cytokinin (Isopentenyladenosine, IPA) in physiologically active concentrations and that its content in HS can stimulate plant metabolism. On the contrary, physiologically active amounts of gibberellins have not yet been detected in HS.

Mora et al., (2010) hypothesized that the effects of HS in plants may involve a primary effect on the root $\mathrm{H}^{+}$-ATPase activity and nitrate root-shoot distribution that, in turn, would cause changes in the root-shoot distribution of certain cytokinins, polyamines and abscisic acid, thus affecting shoot growth. These effects were associated with higher shoot concentration of several cytokinins and polyamines, and a concomitant decrease in their content in roots.

\section{Protein-based biostimulants}

Protein-based products can be divided into two major categories: protein hydrolysates consisting of a mixture of peptides and amino acids of animal or plant origin, and individual amino acids such as glutamate, glutamine, proline and glycine betaine.

Protein hydrolysates are produced through enzymatic, chemical or thermal hydrolysis of a variety of animal and plant residues, including animal epithelial or connective tissues (Cavani et al., 2006; Ertani et al., 2009, 2013a), animal collagen and elastine (Cavani et al., 2006), carobgerm protein (Parrado et al., 2008) and alfalfa plants (Schiavon et al., 2008; Ertani et al., 2009, $2013 \mathrm{~b})$. Individual amino acids include the twenty structural amino acids involved in the synthesis of proteins and non-protein amino acids, which are abundant in some plant species (Vranova et al., 2011). These amino acids are adsorbed by both roots and leaves and then translocated into the plant (Watson and Fowden, 1975; Soldal and Nissen, 1978; Michonneau et al., 2004; Zhang et al., 2015). 
Several studies testing the action of protein hydrolysates in plants, have demonstrated that their first effect was the stimulation of root and leaf biomass (Zhang et al., 2003; Schiavon et al., 2008; Ertani et al., 2009). For instance, Ertani et al., (2009) reported that short-time application of protein hydrolysates incremented the root dry weight of maize plants compared to the untreated plants. These effects were consistent with those induced by HS in plants, which notoriously increase root growth in the short term and promote shoot biomass over longer periods (Nardi et al., 2009). The increase in root dry weight may result in a more successful transplanting of plants, in higher overall plant-biomass productivity and higher yields (Zhang et al., 2003).

The addition of biostimulants to plants also modifies the morphology of plant roots in a similar way to IAA, suggesting that they induce a "nutrient acquisition response" that favors the uptake of nutrients via an increase in the absorptive surface area (Ertani et al., 2012). These effects on growth appear to be distinct from the nutritional effect of an additional nitrogen source (Ertani et al., 2009, 2014).

\section{Mechanism of action}

Despite the mode of action of protein-based biostimulants being mostly unknown, recent studies have identified their target metabolic pathways and some of the mechanisms through which they exert their effects on plants (Schiavon et al., 2008; Ertani et al., 2009; Ertani et al., 2011a; Ertani et al., 2013). In particular, data available so far suggest that protein hydrolyzates may promote nitrogen assimilation in plants via a coordinated regulation of $\mathrm{C}$ and $\mathrm{N}$ metabolism. For instance, a protein hydrolizate derived from alfalfa plants, enhanced shoot biomass production, soluble sugar accumulation and nitrogen assimilation of hydroponicallygrown maize plants (Schiavon et al., 2008). Specifically, this biostimulant increased the activity of three enzymes (malate dehydrogenase, isocitrate dehydrogenase and citrate synthase) functioning in the tricarboxylic acid cycle (TCA) and five enzymes (nitrate reductase, nitrite reductase, glutamine synthetase, glutamate synthase and aspartate aminotransferase) involved in $\mathrm{N}$ reduction and assimilation. The biostimulant-induced up-regulation of the genes coding for these enzymes was confirmed by RT-PCR experiments. In a further investigation, the same biostimulant was found to improve the growth of maize plants cultivated under salinity stress, by increasing the ratio $\mathrm{Na}^{+}$and $\mathrm{K}^{+}$in leaves, and the synthesis of flavonoids (Ertani et al., 2013b).

Similarly to the alfalfa protein hydrolysate, a meat hydrolysate derived from tanning residues increased short-term growth and the macro-element content of maize seedlings, and, concomitantly, decreased nitrate, phosphate and sulfate content (Ertani et al., 2013a). In addition, Vernieri et al., (2006) demonstrated that the application of a protein hydrolysate influenced nitrogen metabolism in plants, speeding up the incorporation of nitrate into proteins, through the activation of $\mathrm{N}$ assimilation-related enzymes. The increased use efficiency of nitrogen was justified by the higher leaf chlorophyll content in treated plants.

Kramer (1980) reported that the perennial ryegrass plants treated with a product based protein and exposed to prolonged high air temperature stress exhibited both an improved photochemical efficiency and membrane thermostability than untreated plants. These results provided consistent and interesting results and showed that foliar applications of protein hydrolysates can positively affect plant tolerance to heat stress (Kauffman III et al., 2007).

In a recent work, Ertani et al., (2014) reported that two biostimulants, one derived from alfalfa plants (AH) provide by ILSA S.p.A., and the other obtained from red grapes (RG), were chemically characterized using enzyme linked immuno-sorbent assays, Fourier transform infrared (FT-IR) and Raman spectroscopies. Two doses $\left(50\right.$ and $100 \mathrm{~mL} \mathrm{~L}^{-1}$ for $\mathrm{RG}$, and 25 and $50 \mathrm{~mL} \mathrm{~L}^{-1}$ for $\mathrm{AH}$ ) of biostimulants were applied to Capsicum chinensis L. plants cultivated in pots inside a tunnel. Both biostimulants contained different amounts of indoleaceticacid and isopentenyladenosine; the $\mathrm{AH}$ spectra exhibited amino acid functional groups in the peptidic structure, while the RG spectra showed the presence of polyphenols, such as resveratrol. These results revealed that at flowering, $\mathrm{RG}$ and $\mathrm{AH}$ increased the fresh weight of leaves and fruits and the number of green fruits, whereas at maturity the biostimulants affected mainly the fresh weight and number of red fruits. At flowering, the leaves of the biostimulant-treated plants contained high amounts of epicatechin, ascorbic acid, quercetin, and dihydrocapsaicin, while at maturity, they exhibited elevated quantities of fructose, glucose, chlorogenic, and ferulic acids. Furthermore, green fruits exhibited high contents of chlorogenic acid, p-hydroxybenzoic acid, p-coumaric acid and antioxidant activity, while both AH- and RG-treated red fruits were highly endowed in capsaicin. The ${ }^{1} \mathrm{H}$ high-resolution magic-angle spinning (HRMAS)-nuclear magnetic resonance (NMR) spectra of red fruits revealed that both products induced high amount of $\mathrm{NADP}^{+}$, whereas RG also increased glucose, fumarate, ascorbate, thymidine and high molecular weight species. These results suggested that AH and RG promoted plant growth and the production of secondary metabolites, such as phenols.

\section{The cases of no-response}

Besides the plant positive effects of biostimulants, there are also several studies (Ruiz et al., 2000; Cerdán et al., 2009; Lisiecka et al., 2011) reporting that foliar applications of commercial protein hydrolysate products from animal origin can cause phytotoxicity and plant growth depression. In some situations, wrong product concentrations or environmental aspects like field conditions may contribute to no-response to biostimulants. For instance, application of biostimulants in excess might induce no-response or negative responses in plants. Asli 
and Neumann (2010) reported that multiple applications of humic acid inhibited the shoot growth of maize grown hydroponically. No-positive effects were also reported by Kirn et al., (2010) in a trial with okra (Abelmoschus esculentus) grown in field soil experiments, as no significant increases in fruits per plant were observed when the recommended dose was not applied. Other conditions which induced no-response to biostimulant application are reported by Calvo et al., (2014).

\section{Final Remarks}

Recent studies support the potential of different types of biostimulants to improve plant biomass, crop yield and resistance to multiple types of stress. In particular, primary and secondary metabolic pathways of leaves and root tissues are recognized as targets of biostimulants. Further research combining functional genomic and proteomic approaches may help to obtain more insights in how biostimulants elicit plant growth, nutrient uptake and stress-tolerance responses in different plant species. In addition, these studies could allow for the identification of markers for beneficial plant responses, which may be useful for the development of new biostimulants.

\section{References}

Aguirre, E.; Leménager, D.; Bacaicoa, E.; Fuentes, M.; Baigorri, R.; Zamarreño, A.M.; García-Mina, J.M. 2009. The root application of a purified leonardite humic acid modifies the transcriptional regulation of the main physiological root responses to Fe deficiency in Fe-sufficient cucumber plants. Plant Physiology and Biochemistry 47: 215-223.

Asli, S.; Neumann, P.M. 2010. Rhizosphere humic acid interacts with root cell walls to reduce hydraulic conductivity and plant development. Plant and Soil 336: 313-322.

Augier, H.; Harada, H. 1972. Cytokinine-like hormone activity in the seaweed thallus $=$ Presence d'hormonos de type cytokinine dans la thalle des algues marines. Comptes Rendus de l'Académie des Sciences 275: 1765-1768 (in French).

Bentler-Mowat, J.A.; Reid, S.M. 1968. Investigations on the radish leaf bioassay for kinetins and demonstration of kinetin-like substances in algae. Annals of Botany 32: 23-32.

Bottomley, W.B. 1914a. Some accessory factors in plant growth and nutrition. Proceedings of the Royal Society B: Biological Sciences 88: 237-247.

Bottomley, W.B. 1914b. The significance of certain food substances for plant growth. Annals of Botany 28: 531-540.

Bottomley, W.B. 1917. Some effects of organic growth-promotion substances (auximones) on the growth of Lemma minor in mineral cultural solutions. Proceedings of the Royal Society B: Biological Sciences 89: 481-505.

Bronick, C.J.; Lal, R. 2005. Soil structure and management: a review. Geoderma 124: 3-22.

Cacco, G.; Dell'Agnola, G. 1984. Plant growth regulator activity of soluble humic complex. Canadian Journal of Soil Science 62: 306-310.

Calvo, P.; Nelson, L.; Kloepper, J.W. 2014. Agricultural uses of plant biostimulants. Plant and Soil 383: 3-41.
Canellas, L.P.; Olivares, F.L.; Okorokova-Facanha, A.L.; Facanha, A.R. 2002. Humic acids isolated from earthworm compost enhance root elongation, lateral root emergence, and plasma membrane H+-ATPase activity in maize roots. Plant Physiology 130: 1951-1957.

Canellas, L.P.; Piccolo, A.; Dobbss, L.B.; Spaccini, R.; Olivares, F.L.; Zandonadi, D.B.; Façanha, A.R. 2010. Chemical composition and bioactivity properties of size-fractions separated from a vermicompost humic acid. Journal of Agricultural and Food Chemistry 78: 457-466.

Canellas, L.P.; Olivares, F.L. 2014. Physiological responses to humic substances as plant growth promoter. Chemical and Biological Technologies in Agriculture 1: 1-11.

Cavani, L.; Halle, A.T.; Richard, C.; Ciavatta, C. 2006. Photosensitizing properties of protein hydrolysate-based fertilizers. Journal of Agricultural and Food Chemistry 54: 9160 -9167.

Çavuşoğlu, K.; Kılıç, S.; Kabar, K. 2008. Effects of some plant growth regulators on stem anatomy of radish seedlings grown under saline $(\mathrm{NaCl})$ conditions. Plant Soil and Environment 54: 428-433.

Cerdán, M.; Sánchez-Sánchez, A.; Oliver, M.; Juárez, M.; Sánchez-Andreu, J.J. 2009. Effect of foliar and root applications of aminoacids on iron uptake by tomato plants. Acta Horticulturae 830: 481-488.

Chen, S.K.; Subler, S.; Edwards, C.A. 2002. Effects of agricultural biostimulants on soil microbial activity and nitrogen dynamics. Applied Soil Ecology 19: 249-259.

Concheri, G.; Nardi, S.; Reniero, F.; Dell'Agnola, G. 1996. Structural characteristics and biological activities of humic substances within the Ah horizon (Calcic-Luvisol). Plant and Soil 179: 65-72.

Dell'Agnola, G.; Nardi, S. 1987. Hormone-like effect of enhanced nitrate uptake induced by depolycondensed humic fractions obtained from Allolobophora rosea and A. caliginosa faeces. Biology and Fertility of Soils 4: 115-118.

Dobbss, L.B.; Canellas, L.P.; Olivares, F.L.; Aguiar, N.O.; Pers, L.E.P.; Azevedo, M.; Spaccini, R.; Piccolo, A.; Façanha, A.R. 2010. Bioactivity of chemically transformed humic matter from vermicompost on plant root growth. Journal of Agricultural and Food Chemistry 58: 3681-3688.

Ertani, A.; Cavani, L.; Pizzeghello, D.; Brandellero, E.; Altissimo, A.; Ciavatta, C.; Nardi, S. 2009. Biostimulant activity of two protein hydrolysates on the growth and nitrogen metabolism in maize seedlings. Journal of Plant Nutrition and Soil Science 172: 237-244.

Ertani, A.; Francioso, O.; Tugnoli, V.; Righi, V.; Nardi, S. 2011a. Effect of commercial Lignosulfonate-Humate on Zea mays L. metabolism. Journal of Agricultural and Food Chemistry 59: 11940-11948.

Ertani, A.; Schiavon, M.; Altissimo, A.; Franceschi, A.; Nardi, S. 2011b. Phenol-containing organic substances stimulate phenylpropanoid metabolism in Zea mays. Journal of Plant Nutrition and Soil Science 174: 496-503.

Ertani, A.; Pizzeghello, D.; Baglieri, A.; Cadili, V.; Tambone, F.; Gennari, M.; Nardi, S. 2012. Agro-industrial residues and their biological activity on maize (Zea mays L.) metabolism. Journal of Geochemical Exploration 129: 103-111.

Ertani, A.; Nardi, S.; Altissimo, A. 2013. Long-term research activity on the biostimulant properties of natural origin compounds. Acta Horticulture 1009: 181-188.

Ertani, A.; Schiavon, M.; Muscolo, A.; Nardi S. 2013a. Alfalfa plant-derived biostimulant stimulate short-term growth of salt stressed Zea mays L. plants. Plant and Soil 364: 145-158.

Ertani, A.; Pizzeghello, D.; Altissimo, A.; Nardi, S. 2013b. Use of meat hydrolysate derived from tanning residues as plant biostimulant. Journal of Plant Nutrition and Soil Science 176: 287-295. 
Ertani, A.; Pizzeghello, D.; Francioso, O.; Sambo, P.; Sanchez-Cortes, S.; Nardi, S. 2014. Capsicum chinensis L. growth and nutraceutical properties are enhanced by biostimulants in a long-term period: chemical and metabolomic approaches. Frontiers in Plant Science 5: 1-12.

Giannattasio, M.; Vendramin, E.; Fornasier, F.; Alberghini, S.; Zanardo, M.; Stellin, F.; Concheri, G.; Stevanato, P.; Ertani, A.; Nardi, S.; Rizzi, V.; Piffanelli, P.; Spaccini, R.; Mazzei, P.; Piccolo, A.; Squartini, A. 2013. Microbiological features and bioactivity of a fermented manure product (Preparation 500) used in biodynamic agriculture. Journal of Microbiology and Biotechnology 23: 644-651.

Goulding, K. 2000. Nitrate leaching from arable and horticultural land. Soil Use Management 16: 145-151.

Graber, E.R.; Rudich, Y. 2006. Atmospheric HULIS: How humic-like are they? A comprehensive and critical review. Atmospheric Chemistry Physics 6: 729-753.

Hussain, A.; Boney, A.D. 1969. Isolation of Kinin-like substances from Laminaria digitata. Nature 223: 504.

Jennings, R.C. 1969. Gibberellin antagonism by material from brown algae. New Phytology 68: 683-688.

Jindo, K.; Martim, S.A.; Navarro, E.C.; Pérez-Alfocea, F.; Hernandez, T.; Garcia, C.; Aguiar, N.O.; Canellas, L.P. 2012. Root growth promoting by humic acids from composted and non-composted urban organic wastes. Plant and Soil 353: 209220.

Kalbitz, K.; Solinger, S.; Park, J.H.; Michalzik, B.; Matzner, E. 2000. Controls on the dynamics of dissolved organic matter in soils: a review. Soil Science 165: 277-304.

Kauffman III, G.L.; Kneivel, D.P.; Watschke, T.L. 2007. Effects of a biostimulant on the heat tolerance associated with photosynthetic capacity, membrane thermostability, and polyphenol production of perennial ryegrass. Crop Science 47: 261-267.

Kirn, A.; Kashif, S.R.; Yaseen, M. 2010. Using indigenous humic acid from lignite to increase growth and yield of okra (Abelmoschus esculentus L.). Soil \& Environment 29: 187-191.

Kovács, K.; Czech, V.; Fodor, F.; Solti, A.; Lucena, J.J.; SantosRosell, S.; Hernández-Apaolaza, L. 2013. Characterization of Fe-Leonardite complexes as novel natural iron fertilizers. Journal of Agricultural and Food Chemistry 61 : 12200-12210.

Kramer, P.J. 1980. Drought, stress, and the origin of adaptations. p. 7-20. In: Turner, N.C.; Kramer, P.J., eds. Adaptation of plants to water and high temperature stress. John Wiley, New York, NY, USA.

Kumaravelu, G.; Livingstone, V.D.; Ramanujam, M.P. 2000. Triacontanol-induced changes in the growth, photosynthetic pigments, cell metabolites, flowering and yield of green gram. Biologia Plantarum 43: 287-290.

Lebuhn, M.; Hartmann, A. 1993. Method for determination of indole-3-acetic acid andrelated compounds of L-tryptophan catabolism in soils. Journal of Chromatography. 629: 255-266.

Lisiecka, J.; Knaflewski, M.; Spizewski, T.; Fraszczak, B.; Kaluzewicz, A.; Krzesin- ski, W. 2011. The effect of animal protein hydrolysate on quantity and quality of strawberry daughter plants cv. 'Elsanta'. Acta Scientiarum Polonorum Horticulture 10: 31-40.

Michonneau, P.; Roblin, G.; Bonmort, J.; Fleurat-Lessard, P. 2004. Valine uptake in the tap root of sugar beet: a comparative analysis with sucrose uptake. Journal of Plant Physiology 161: 1299-1314.
Mora, V.; Bacaicoa, E.; Zamarreno, A.M.; Aguirre, E.; Garnica, M.; Fuentes, M.; Garcia-Mina, J.M. 2010. Action of humic acid on promotion of cucumber shoot growth involves nitraterelated changes associated with the root-to-shoot distribution of cytokinins, polyamines and mineral nutrients. Journal of Plant Physiology 167: 633-642.

Muscolo, A.; Panuccio, M.R.; Abenavoli, M.R.; Concheri, G.; Nardi, S. 1996. Effect of molecular complexity and acidity of earthworm faeces humic fractions on glutamate dehydrogenase, glutamine synthetase, and phosphoenolpyruvate carboxylase in Daucus carota II cells. Biology and Fertility of Soils 22: 83-88.

Muscolo, A.; Cutrupi, S.; Nardi, S. 1998. IAA detection in humic substances. Soil Biology \& Biochemestry 30: 1199-1201.

Muscolo, A.; Sidari, M.; Francioso, O.; Tugnoli, V.; Nardi, S. 2007a. The auxin-like activity of humic substances is related to membrane interaction in carrot cell cultures. Journal of Chemical Ecology 33: 115-129.

Muscolo, A.; Sidari, M.; Attinà, E.; Francioso, O.; Tugnoli, V.; Nardi, S. 2007b. Biological activity of humic substances is related to their chemical structure. Soil Science Society of America Journal 71: 75-85.

Nardi, S.; Arnoldi, G.; Dell'Agnola, G. 1988. Release of the hormone-like activities from Allolobophora rosea and $\mathrm{A}$. caliginosa faeces. Canadian Journal of Soil Science 68: 563-567.

Nardi, S.; Pizzeghello, D.; Reniero, F.; Rascio, N. 2000. Chemical and biochemical properties of humic substances isolated from forest soils and plant growth. Soil Science Society of America Journal 64: 639-645.

Nardi, S.; Pizzeghello, D.; Muscolo, A.; Vianello, A. 2002a. Physiological effects of humic substances on higher plants. Soil Biology \& Biochemistry 34: 1527-1536.

Nardi, S.; Sessi, E.; Pizzeghello, D.; Sturaro, A.; Rella, R.; Parvoli, G. 2002b. Biological activity of soil organic matter mobilized by root exudates. Chemosphere 46: 1075-1081.

Nardi, S.; Tosoni, M.; Pizzeghello, D.; Provenzano, M.R.; Cilenti, A.; Sturaro, R.; Vianello, A. 2005. A comparison between humic substances extracted by root exudates and alkaline solution. Soil Science Society of America Journal 69: 2012-2019.

Nardi, S.; Carletti, P.; Pizzeghello, D.; Muscolo, A. 2009. Biological activities of humic substances, in biophysicochemical processes involving natural nonliving organic matter in environmental systems. In: Senesi, N.; Xing, B.; Huang, P.M., eds. Part I. Fundamentals and impact of mineral-organicbiota interactions on the formation, transformation, turnover, and storage of natural nonliving organic matter (NOM). John Wiley, Hoboken, NJ, USA.

O'Donnell, R.W. 1973. The auxin-like effects of humic preparations from leonardite. Soil Science 116: 106-112.

Parrado, J.; Bautista, J.; Romero, E.J.; García-Martínez, A.M.; Friaza, V.; Tejada, M. 2008. Production of a carob enzymatic extract: potential use as a biofertilizer. Bioresource Technology 99: 2312-2318.

Piccolo, A.; Nardi, S.; Concheri, G. 1992. Structural characteristics of humic substancesas related to nitrate uptake and growth regulation in plant systems. Soil Biology \& Biochemistry 24: 373-380.

Piccolo, A. 2001. The supramolecular structure of humic substances. Soil Science 166: 810-833. 
Piccolo, A. 2002. The supramolecular structure of humic substances: a novel understanding of humus chemistry and implications in soil science. Advances in Agronomy 75: 57-134.

Pizzeghello, D.; Nicolini, G.; Nardi, S. 2001. Hormone-like activity of humic substances in Fagus sylvaticae L. forests. New Phytologist 151: 647-657.

Pizzeghello, D.; Nicolini, G.; Nardi, S. 2002. Hormone-like activities of humic substances in different forest ecosystems. New Phytologist 155: 393-402.

Pizzeghello, D.; Francioso, O.; Ertani, A.; Muscolo, A.; Nardi S. 2013. Isopentenyladenosine and cytokinin-like activity of four humic substances. Journal of Geochemical Exploration 129: 70-75.

Rademacher, W. 1992. Occurrence of giberellins in different species of the fungal genera Sphaceloma and Elsinoe. Phytochemistry 31: 4155-4157.

Ries, S.K.; Violet, W. 1977. Growth responses of rice seedlings to triacontanol in light and dark. Planta 135: 77-82.

Ruiz, J.M.; Castilla, N.; Romero, L. 2000. Nitrogen metabolism in pepper plants applied with different bioregulators. Journal of Agricultural and Food Chemistry 48: 2925-2929.

Salma, I.; Meszaros, T.; Maenhaut, W.; Vass, E.; Majer, Z. 2010. Chirality and the origin of atmospheric humic-like substances. Atmospheric Chemistry Physics 10: 1315-1327.

Schiavon, M.; Ertani, A.; Nardi, S. 2008. Effects of an alfalfa protein hydrolysate on the gene expression and activity of enzymes of TCA cycle and $\mathrm{N}$ metabolism in Zea mays L. Journal of Agricultural and Food Chemistry 56: 11800-11808.

Schulten, H.R.; Schnitzer, M. 1998. The chemistry of soil organic nitrogen: a review. Biology and Fertility of Soils 26: 1-15.

Soldal, T.; Nissen, P. 1978. Multiphasic uptake of amino acids by barley roots. Physiologia Plantarum 43: 181-188.

Stevenson, F.J. 1994. Humus Chemistry: Genesis, Composition, Reactions. 2ed. Wiley, New York, NY, USA.
Trevisan, S.; Pizzeghello, D.; Ruperti, B.; Francioso, O.; Sassi, A.; Palme, K.; Quaggiotti, S.; Nardi, S. 2009. Humic substances induce lateral root formation and expression of the early auxin-responsive IAA19 gene and DR5 synthetic element in Arabidopsis. Plant Biology 12: 604-614.

Trevisan, S.; Botton, A.; Vaccaro, S.; Vezzaro, A.; Quaggiotti, S.; Nardi, S. 2011. Humic substances affect Arabidopsis physiology by altering the expression of genes involved in primary metabolism, growth and development. Environmental and Experimental Botany 74: 45-55.

Vasconcelos, A.C.F.; Zhang, X.Z.; Ervin, E.H.; Kiehl, J.D. 2009. Enzymatic antioxidant responses to biostimulants in maize and soybean subject to drought. Scientia Agricola 66: 395-402.

Vernieri, P.; Ferrante, A.; Borghesi, E.; Mugnai, S. 2006. Biostimulants: a tool for improving quality and yield = Biostimolanti: uno strumento per migliorare la qualità delle produzioni. Fertilitas Agrorum 1: 17-22 (in Italian, with abstract in English).

Vranova, V.; Rejsek, K.; Skene, K.R.; Formanck, P. 2011. Non-protein amino acids: plant, soil and ecosystem interactions. Plant and Soil 342: 31-48.

Watson, R.; Fowden, L. 1975. The uptake of phenylalanine and tyrosine by seedling root tips. Phytochemistry 14:1181-1186.

Zandonadi, D.B.; Santos, M.P.; Dobbss, L.B.; Olivares, F.L.; Canellas, L.P.; Binzel, M.L.; Okorokova-Façanha, A.L.; Façanha, A.R. 2010. Nitric oxide mediates humic acids-induced root development and plasma membrane $\mathrm{H}^{+}$-ATPase activation. Planta 231: 1025-1036.

Zhang, D.; Hamauzu, Y. 2003. Phenolic compounds, ascorbic acid, carotenoids and antioxidant properties of green, red and yellow bell peppers. Journal of Food, Agriculture and Environment 1: 22-27.6

Zhang, L.; Garneau, M.G.; Majumdar, R.; Grant, J.; Tegeder, M. 2015. Improvement of pea biomass and seed productivity by simultaneous increase of phloem and embryo loading with amino acids. Plant Journal 81: 134-146. 